\title{
The Influence of Personality, Organizational Culture and Organizational Commitment Toward Organizational Citizenship Behavior Ant Their Impacts on the Performance of Employees at KPP Pratama Lhokseumawe
}

\author{
Yanita $^{1}$, Aulia Rahmat ${ }^{1}$ and Ihsan ${ }^{1}$ \\ \{1yanita61@yahoo.com, ${ }^{2}$ second.author@second.com, ${ }^{3}$ third.author@first-third.edu\} \\ ${ }^{1}$ Management Department Economic and Business Faculty, Malikussaleh University, Lhokseumawe \\ Indonesia
}

\begin{abstract}
This study was conducted to examine the influence of personality, organizational culture, and organizational commitment to the performance of the employee with organizational citizenship behavior as the intervening variable at KPP Pratama Lhokseumawe. The population used in this study was 83 respondents, while the sample of research as many as 79 respondents based on the questionnaires. The samples were taken using Census sampling technique. The hypothesis tests were conducted by using path analysis with the help of SPSS. The results of hypothesis tests indicated that personality, organizational culture, and organizational commitment have significant effects on organizational citizenship behavior. Organizational culture and organizational commitment have a significant effect on the performance of the employee, while personality had no significant effect on the performance of employees. The result of examination of mediation variable showed that organizational citizenship behavior could mediate the relationship between personality and organizational culture to partial employee performance. Whereas in organizational commitment, organizational citizenship behavior perfectly mediated the performance of employees.
\end{abstract}

Keywords: Personality, Organizational Culture, Organizational Commitment, Organizational Citizenship Behavior and Employee Performance

\section{Introduction}

Human resources are the most important asset and functions as capital in an organization, capital what is meant here is nonfinancial capital that can be used as real potential physically and non-physically in realizing an existence organization. The role of employees as managers of the organization as a whole is important for the success of an organization. The main task of the Primary KPP is to carry out counseling. service and supervision of taxpayers in the field of income tax Value Added Tax, Sales Tax on Luxury Goods, No Taxes Other direct in the area of authority based on regulations current regulation. Theoretically and empirically, personality factors, organizational culture, and organizational commitment can affect OCB behavior and performance on employees. in this study will be seen "The Influence of Personality, Culture Organization, and Organizational Commitment to Organizational Citizenship Behavior (OCB) and its impact on the Performance of Primary KPP Employees Lhokseumawe ". 


\section{Literature Review}

\subsection{Human Resources (HR)}

An Source management human power according to (Dessler, 2011) is a policy and practice inside move human resources or aspects related to management positions at in human resources which includes recruitment activities, screening, training, awarding and assessment. Human resource management relate to the total set of knowledge, skills and attitudes the company needs to complete.

\subsection{Personality}

Your Personality is the overall attitude, expression, feeling and behaviour someone. This will manifest in one's actions if faced with certain situations. Everyone has behavioral tendencies which applies consistently in the face of situations he faced it, so it became his personal characteristic. The word personality itself comes from language Latin "persona" which means mask used by actors in one game or show. The actors hide their personalities original, and displays itself according to the mask he uses. But in psychology, personality is not just outer appearance, (Feist and Feist, 2009) argue that personality includes physical and psychological systems that include visible behavior and thoughts not visible. This means that individual personality is not just a mask used (showing behavior), but individual personality also refers on what lies behind the outer appearance and also what is containedbehind his actions.

\subsection{Organizational culture}

Organizational culture is overall values, norms, beliefs, where are opinions what is followed then is upheld jointly by the members organization. With culture, it will give direction and style to members within the organization, creating customs (customs) and something tradition.

Organizational culture is interpreted as a group values and norms that control interaction between members organization or organization members with parties outside the organization. Value is a criterion, standard or principles that become a reference for each individuals in determining the desired behavior, situation and results unwanted. Through the expression "it's the way we do things here, its part of our culture", (Vecchio, 2006) defines organizational culture as a collection of values and existing (established) norms in an organization then taught or given to workers who join the organization that. This can mean that the values and norms that have been formed like it has become a system within the organization and made a belief or mutual reference when individuals behave. System is a set of key characteristics that are upheld by the organization (Robbins and Judge, 2008) so that new workers or those who have joined in the organization must know the rules of the game contained in it and that must be obeyed and practiced when they interact and complete taskshis job.

\subsection{Organizational Commitment}

(Luthans, 2006) argues that organizational commitment is an attitude that reflects employee loyalty to the organization and where there is an ongoing process individual members of the organization devote their attention to sustainability organizational success and progress. It can be said that among employees and the organization has an emotional or spiritual relationship, where employees who are involved in an organization are not only 
determined as a worker, but there is also a sense of belonging (organizational belongingness) between them (Dan and Zhang, 2010).

Whereas (Srivastava, 2015) that organizational commitment is a relative strength of the individual in identifying his involvement in the organization, which conceptually can be marked by three things:

- Strong trust and acceptance of values and goals organization

- Readiness and willingness to try earnestly on behalf of organization

- A strong desire to maintain membership inside organization (being part of the organization)

So it can be concluded, organizational commitment is identification employee involvement in the organization caused by its existence formal relationship between each other. Organizations are bound to give formal rewards such as wages or other facilities, while employees are trusted joining organizations is bound to carry out tasks and functions according to the role.

\subsection{Organizational Citizenship Behavior (OCB)}

Employees have an important role for success organization. The contribution of employees to the organization is usually measured based on the performance achieved according to the job description for its role. (Robbins and Judge, 2008) argues, actually successful organizations also need employees who can produce performance beyond the expectations of the organization or want do what exceeds their usual duties, that is by displays Organizational Citizenship Behavior (OCB).

On the other hand, (Allameh, Shahriari and Mansoori, 2012) identified employees actually must have three things in relation to contributing towards the success of an organization, namely:

- Employees must have the motivation to join and stay in organization

- Employees must carry out their work based on the job description and its role is in accordance with what has been determined by the organization; and

- Employees must participate or conduct activities that are innovative and spontaneously exceeds the perception of its role in an organization

Of the three things above, the employee with this last category is on call good citizenship (Griffin and Moorhead, 2012), namely employees who are have OCB or the extra role behavior. Whereas (Borman, 2004) looking at OCB through the concept of prosocial behavior, which is defined as "The behavior that is directed toward individuals, groups, or organizations with the intention of promoting their welfare, namely behavior that is done directly for individuals, groups, or organizations that aim to improve their welfare. (Mayfield and Taber, 2010) identify behaviour prosocial or OCB includes helping others and being volunteer for extra tasks, where this behavior is positive, constructive and meaningful help. The desire to be a volunteer based on high social enthusiasm. Individuals believe through extra tasks will provide benefits to other people, groups, or organizations so in the end the individual himself will feel it (Kane et al., 2011).

The definition of OCB is more profoundly described by Organ et al. (2006) namely Discretionary behavior that is not direct or explicitly get an award from a formal reward system, and as a whole (aggregate) will increase the efficiency and effectiveness of functions organization. This behavior is free and voluntary, because it is not required by the role requirements or job descriptions / positions that are clearly demanded based on contract with the organization but as a personal choice. 


\section{Result And Discussion}

\subsection{Analysis Results of the Effect of Personality Variables, Organizational Culture and Organizational Commitment to OCBFont of Entire Document}

To analyze the influence of personality, organizational culture and Organizational commitment to OCB is done by using assistance SPSS. The first analysis done is the equation of substructure 1: The substructure equation 1 is:

$\mathrm{Y} 1=\mathrm{b} 1 \mathrm{X} 1+\mathrm{b} 2 \mathrm{X} 2+\mathrm{b} 3 \mathrm{X} 3+\mathrm{e} 1$

Where

$\mathrm{Y} 1=\mathrm{OCB}$

$\mathrm{X} 1=$ Personality

$\mathrm{X} 2$ = Organizational Culture

X3 = Organizational Commitment

Analysis of Model Tables Summary Sub Structure 1:

- In the Summary Model output, the $\mathrm{R}$ value is 0.705 , this is the case shows that there is a positive correlation between personality variables, organizational culture and organizational commitment to OCB.

- In the Summary Model output, the value of Adjusted R Square is obtained by 0.477 means that the OCB variable can be explained by personality, culture variables organization and organizational commitment of $47.7 \%$ while the remaining amount is $52.3 \%$ determined the variation of other variables that were not examined.

Coefficient Table Analysis Sub Test Structure 1

- In the output coefficient, we can see the Standardized Coefficient (Beta) or personality path coefficient of OCB is 0.386 . Path coefficient organizational culture towards OCB is 0.258 . Coefficient of commitment path organization against OCB is 0.207 . At the output values are obtained Sig. personality of 0,000 and Sig. organizational culture of 0.016 and Sig Value. organizational commitment of 0.037 . All $t$ values are greater from the $t$ table value of 1.665 with a value of Sig. $<0.05$ with the direction of the coefficient positive. Thus, it can be concluded that personality, culture organization and organizational commitment influence OCB.

- The X1 regression coefficient of 0.386 states that if the variable personality which includes level of accuracy, level of emotional stability, ease of agreement, social skills and openness on the experience of Lhokseumawe KPP Pratama employees, it will there was an increase in OCB as measured by a Likert scale, assuming organizational culture and organizational commitment are of constant value.

- The regression coefficient X2 of 0.258 states that if the variable is culture organizations like innovation and courage to take risks, attention in detail, focus on results, work teamwork, oriented on the individual and stability provided by the Primary KPP Lhokseumawe, there will be an increase in employee OCB measured with a Likert scale, with personality assumptions and organizational commitment constant value.

- The X3 regression coefficient of 0.207 states that if the variable is commitment organization like the similarity between personality values with organization, pride in being a member of the organization, an attitude of approval organizational policy, organizations inspire to be more accomplished, persistent effort for successful 
organization, active involvement in loyal assignments and a high sense of loyalty to the organization are given by The Primary KPP Lhokseumawe was upgraded again, so there will be an increase OCB is measured by a likert scale, with personality and organizational culture is of constant value. From the results of the statistical tests that have been done, the equation for substructure 1 is:

$\mathrm{Y} 1=0,386 \mathrm{X} 1+0,258 \mathrm{X} 2+0,207 \mathrm{X} 3+\mathrm{e} 1$

\subsection{Effect of Personality on OCB}

Linear regression results of the first sub structure model show that hypothesis 1 is accepted, where variable personality has a significant effect on OCB at the Primary KPP Lhokseumawe. Based on this research can also explained that personality has a significant positive effect on OCB employee of the KPP Pratama Lhokseumawe. The results of this study support the research of (Najari, Ahmadi and Habibitabar, 2011) and opinion of (Wardani and Suseno, 2012), where individuals display action or behavior depends very much on mood and personality. Mood often or can change, while personality seen as self-inherent character and harder to change, so that the influence of the personality is more consistent and enduring the appearance of OCB.

\subsection{The Influence of Organizational Culture on OCB}

Linear regression results of the first sub structure model show that organizational culture variables have a significant effect towards OCB at the Primary KPP Lhokseumawe. This can be interpreted, if organizational culture increases in the sense that, if the respondent has innovation and courage to take risks, attention to detail, focus on results, aggressiveness, work in teamwork, management oriented individual and stability in work, the OCB is at the Primary KPP Lhokseumawe will increase. The results achieved are in accordance with the research by (Mohanty and Rath, 2012; Oemar, 2013) and (Darsana, 2013), the results of which are also states that organizational culture has a significant and positive direct effect against OCB.

\subsection{Effect of Organizational Commitment to OCB}

Linear regression results of the first sub structure model show that influential organizational commitment variables significant to OCB at the Lhokseumawe Primary KPP. This can interpreted, if organizational commitment increases in the sense that, if the respondent have strong trust and acceptance of values and goals organization, readiness and willingness to be serious on behalf of organization, and a strong desire to maintain membership inside organization, then OCB at the Primary KPP Lhokseumawe will increase. The results achieved are in accordance with research by, (Jo and Joo, 2011; Oemar, 2013), whose results also state that organizational commitment has a significant direct and positive impact on OCB.

\subsection{Results of Analysis of the Effect of Personality Variables, Organizational Culture, Organizational Commitment and OCB on Employee Performance}

The next stage of analysis is to analyze the effect variable personality, organizational culture, organizational commitment and OCB towards the performance of Lhokseumawe Primary KPP employees is done using help SPSS 22.0 for windows. The second analysis is the equation substructure 2 : The substructure equation 2 is: 
$\mathrm{Y} 2=\mathrm{b} 1 \mathrm{X} 1+\mathrm{b} 2 \mathrm{X} 2+\mathrm{b} 3 \mathrm{X} 3+\mathrm{b} 4 \mathrm{Y} 1+\mathrm{e} 2$

Where :

Y2 = Employee Performance

$\mathrm{Y} 1=\mathrm{OCB}$

$\mathrm{X} 1=$ Personality

$\mathrm{X} 2$ = Organizational Culture

X3 = Organizational Commitment

Analysis of the second substructure was carried out to determine the effect personality variables (X1), organizational culture (X2), organizational commitment (X3) and OCB (Y1) on employee performance (Y2) at KPP Pratama Lhokseumawe.

Analysis Model Summaryb Sub Test Structure 2:

- In the Summary Model output, the $\mathrm{R}$ value is 0.803 , this is the case shows that there is a positive correlation between personality variables, organizational culture, organizational commitment and OCB on employee performance.

- In the Summary Model output, the value of Adjusted R Square is obtained by 0.626 means that employee performance variables can be explained by variables personality, organizational culture, organizational commitment and OCB of $62.6 \%$ while the remaining $37.4 \%$ is determined by variations in other variables that are not researched.

Analysis of Coefficienta Sub Test Structure 2:

- In the output coefficient, we can see the Standardized Coefficient (Beta) or personality path coefficient of employee performance is 0.125 . Coefficient organizational culture pathway towards employee performance is 0.202 . Coefficient the path of organizational commitment to employee performance is 0.224 . Coefficient OCB path to employee performance is 0.422 . At the output the value of Sig. personality of 0.191 and Sig. organizational culture amounting to 0.032 and Sig. organizational commitment of 0.010 and Value Sig. OCB is 0,000. All things except larger personality variables from the $t$ table value of 1.993 with the value of Sig. $<0.05$ and direction of the coefficient positive, thus it can be concluded that personality is not influence the performance of Lhokseumawe KPP Pratama employees because Sig value. greater than 0.05 and $\mathrm{t}$ counts more than 1.993. Whereas culture organization, organizational commitment and OCB affect performance employee.

- The regression coefficient X1 of 0.125 states that if the variable personality which includes level of accuracy, level of emotional stability, ease of agreement, social skills and openness to the experience of the Lhokseumawe Primary KPP employee improved, there will be an increase in the performance of the measured employee with a Likert scale, assuming organizational culture and commitment organization is of constant value.

- The X2 regression coefficient of 0.202 states that if the variable is culture organizations like innovation and courage to take risks, attention in detail, focus on results, work in a teamwork, oriented manner on the individual and stability provided by the Primary KPP Lhokseumawe, there will be an increase in the measured performance of employees with a Likert scale, with personality assumptions, organizational commitment and OCB is of constant value.

- The X3 regression coefficient of 0.224 states that if the commitment variable organization like the similarity between personality values with organization, pride in being a member of the organization, an attitude of approval organizational policy, 
organizations inspire to be more accomplished, persistent effort for successful organization, active involvement in loyal assignments and a high sense of loyalty to the organization are given by The Primary KPP Lhokseumawe was upgraded again, so there will be an increase employee performance as measured by a likert scale, with personality assumptions, organizational culture and OCB are of constant value.

- The regression coefficient Y1 of 0.422 states that if the variable OCB like Altruism, Conscientiousness, Courtesy, Sportmanship, Civic Virtue given by the staff of the Primary KPP Lhokseumawe improved again there will be an increase in employee performance as measured by a Likert scale, with personality assumptions, organizational culture and organizational commitment constant value.

From the results of the statistical tests that have been done, the equation for substructure 2 is: $\mathrm{Y} 2=0,125 \mathrm{X} 1+0,202 \mathrm{X} 2+0,224 \mathrm{X} 3+0,422 \mathrm{Y} 1+\mathrm{e} 2$

The results showed that personality, organizational culture, and organizational commitment influences OCB as well as employee performance in KPP Pratama Lhokseumawe. This means changes that occur at OCB variables and employee performance can be explained or influenced together by personality variables, organizational culture, and organizational commitment. Based on the results of the analysis between OCB on employee performance shows there is a positive and significant influence. This indicates that he higher the employees take the initiative to help coworkers voluntarily (altruism), behaving following conscientiousness, guarding good relations with colleagues (courtesy), willing to accept the provisions organization (sportmanship), and has the responsibility to be involved and care on civic virtue, it will have an impact on increase employee performance. This finding is in accordance with (Mayfield and Taber, 2010) who stated OCB as positive, constructive behaviour meaningful to help, and volunteer or volunteer for assignments extras outside the main job, so as to have an effect on the increase employee performance. This result also supports the research of (Biswas and Varma, 2007; Darsana, 2013; Sani, 2013; Tehran, Abtahi and Esmaeili, 2013). Based on this research can also be explained that personality significantly positive effect on OCP Primary KPP employees Lhokseumawe. The results of this study support the research of (Najari, Ahmadi and Habibitabar, 2011) and opinion of (Wardani and Suseno, 2012), where individuals display action or behavior depends very much on mood and personality. Mood often or can change, while personality seen as self-inherent character and harder to change, so that the influence of the personality is more consistent and enduring the appearance of OCB.

\section{Conclusions}

- State of organizational culture and commitment of Primary KPP employees Lhokseumawe in general can be said to be in the high / good category. Furthermore, the state of personality is still less strong. Employees too indicates willingness to behave OCB and employee performance can well categorized, but still not in the expected condition the head of the Primary KPP Lhokseumawe.

- Personality, organizational culture, organizational commitment affect OCB at KPP Pratama Lhokseumawe.

- Organizational culture, organizational commitment and OCB influence employee performance at KPP Pratama Lhokseumawe. While personality partial does not affect the performance of employees at the Primary Tax Office Lhokseumawe.

- Personality, organizational culture and organizational commitment influence indirectly on employee performance through OCB at Primary KPP Lhokseumawe. 


\section{Acknowledgment}

Awards are given to all related parties and contribute in various forms in the completion of writing. All parties in the research object in this study, educational institutions that help by facilitating the completion of this paper and personnel who are directly and indirectly involved in the completion of this paper. Hopefully Barakah.

\section{References}

[1] Allameh, S. M., Shahriari, M. and Mansoori, H. (2012) 'Investigating Employee's Attitude Toward Organization, Organizational Climate and Employee 's Engagement as Antecedents of Organizational Citizenship Behavior $\mathrm{PhD}$. Candidate of Business Administration , Faculty of Administrative Science and Economics', Australian Journal of Basic and Applied Sciences, 6(8), pp. 384-393.

[2] Biswas, S. and Varma, A. (2007) 'Psychological climate and individual performance in India: test of a mediated model', Employee Relations, 29(6), pp. 664-676. doi: $10.1108 / 01425450710826131$.

[3] Borman, W. C. (2004) 'The Concept of Organizational Citizenship', Organizational Citizenship performance, 13(6), pp. 6-9.

[4] Dan, W. and Zhang, D. (2010) 'Relationship among Organizational Support, Organizational Commitment and Organizational Citizenship Behavior of University Faculty Members', in International Conference on Management Science \& Engineering (17th), pp. 1769-1775.

[5] Darsana, M. (2013) 'The Influence Of Personality And Organizational Culture On Employee Performance Through Organizational Citizenship Behavior', THE INTERNATIONAL JOURNAL OF MANAGEMENT, 2(4), pp. 35-42.

[6] Dessler, G. (2011) Manajemen Sumber Daya Manusia. Jakarta: Penerbit Indeks.

[7] Feist, J. and Feist, J. . (2009) Theories of Personality. 7 th Editi. USA: McGraw-Hill.

[8] Griffin, W. R. and Moorhead, G. (2012) Organizational Behavior: Managing People and Organizations. 8th editio. US: South-Western Cengage Learning.

[9] Jo, S. J. and Joo, B.-K. (2011) 'Knowledge Sharing: The Influences of Learning Organization Culture, Organizational Commitment, and Organizational Citizenship Behaviors', Journal of Leadership \& Organizational Studies, 18(3), pp. 353-364. doi: $10.1177 / 1548051811405208$.

[10] Luthans, F. (2006) Organizational Behavior. Edisi Terj. Edited by V. A. Yuwono et al. Yogyakarta: Andi.

[11] Mayfield, C. O. and Taber, T. D. (2010) 'A prosocial self-concept approach to understanding organizational citizenship behavior', Journal of Managerial Psychology, 25(7), pp. 741-763. doi: 10.1108/02683941011075283.

[12] Mohanty, J. and Rath, B. P. (2012) 'Influence of organizational culture on organiztional citizhenship behavior: A three-sector study', GLOBAL JOURNAL OF BUSINESS RESEARCH, 6(1), pp. 65-76.

[13] Najari, R., Ahmadi, F. and Habibitabar, Z. (2011) 'Study of relationship between personality and organizational citizenship behavior (OCB) in public organizations in Iran', Interdisciplinary Journal of Contemporary Research in Business. Available at: http://connection.ebscohost.com/c/articles/70548052/study-relationship-betweenpersonality-organizational-citizenship-behavior-ocb-public-organizations-iran 
(Accessed: 22 January 2019).

[14] Oemar, Y. (2013) 'Pengaruh Budaya Organisasi , Kemampuan Kerja dan Komitmen Organisasi terhadap Organizational Citizenhsip Behavior ( OCB ) Pegawai pada BAPPEDA Kota Pekanbaru', Jurnal Aplikasi Manajemen, 11(1), pp. 65-76.

[15] Robbins, P. S. and Judge, A. . (2008) Organizational Behavior. Edisi 12 B. Edited by D. Angelica and R. Cahyani. Jakarta: England: Longman Publishing.Longman Publishing.

[16] Sani, A. (2013) 'Role of Procedural Justice , Organizational Commitment and Job Satisfaction on job Performance: The Mediating Effects of Organizational Citizenship Behavior', International Journal of Business and Management, 8(15), pp. 57-67. doi: 10.5539/ijbm.v8n15p57.

[17] Srivastava, S. (2015) 'Organizational Citizenship Behaviour as a Function of Organizational Commitment and Corporate Citizenship in Organizations', Management and Labour Studies, 33(3), pp. 311-337.

[18] Tehran, G. M., Abtahi, M. S. and Esmaeili, S. (2013) 'The Relationship between Organizational Citizenship Behavior and Performance of the Staff of Qazvin University of Medical Sciences and Health Services', International Journal of Academic Research in Business and Social Sciences, 3(9), pp. 534-542. doi: 10.6007/IJARBSS/v3-i9/239.

[19] Vecchio, P. . (2006) Organizational Behavior: Core Concepts. 6th Editio. U.S: Thomson South-Western.

[20] Wardani, A. K. and Suseno, M. N. (2012) 'Faktor kepribadian dan Organizational Citizhenship Behavior Pada Polisi Pariwisata’, Humanitas, 9(2), pp. 193-204. 